\title{
Impacts of urbanization on mangrove forests and brachyuran crabs in Penang, Malaysia
}

\author{
Johann Stiepani ${ }^{1,2,3}$ (D) Lucy Gwen Gillis ${ }^{2} \cdot$ Su Yin Chee ${ }^{4} \cdot$ Martin Pfeiffer $^{1} \cdot$ Inga Nordhaus $^{2}$
}

Received: 2 November 2019 / Accepted: 6 June 2021 / Published online: 18 June 2021

(C) The Author(s) 2021

\begin{abstract}
Urban development is driving the loss and subsequent fragmentation of mangrove forests in Penang, Malaysia. However, little research has focused on the implications of urbanization onto the biodiversity within mangrove forests. This study investigates and compares both vegetation and crab assemblages between urban and rural mangrove forests. Collectively, 5853 trees were recorded including 15 species from six families: Acanthaceae, Arecaceae, Lythraceae, Malvaceae, Meliaceae, and Rhizophoraceae. Avicennia marina accounted for $88.6 \%$ of all trees in the study and held the highest species importance (IV). Although the total number of mangrove tree species varied significantly between urban (14) and rural (7) mangrove forests, the mangrove forest structure based on IV did not vary significantly. In total, 633 crabs were recorded comprising 13 different species from three superfamilies: Grapsoidea, Ocypodoidea, and Paguroidea. Crab species richness did not vary between urban and rural sites, but the biomasses of five and the densities of four crab species varied significantly. Redundancy analysis (RDA) indicated that land use, salinity, and abundance of Avicennia officinalis can best describe the distribution of crab species $\left(\mathrm{r}^{2}\right.$ $=32.7$ ). This study indicates that smaller fragmented urban mangroves at the east coast of Penang have a relatively high tree and crab diversity and are worth protecting, in addition to the larger mangrove forests on the west coast. The preservation of small yet interconnected mangrove sites could be critical to the recruitment of their flora and fauna and should be considered in decisionmaking processes.
\end{abstract}

Keywords Urbanization · Mangrove ecology $\cdot$ Brachyuran crabs $\cdot$ Indo-West Pacific (IWP)

\section{Introduction}

Mangrove forests are coastal ecosystems that exist between the latitude of $30^{\circ} \mathrm{S}$ and $30^{\circ} \mathrm{N}$ (Alongi 2002; Ricklefs et al. 2006; Giri et al. 2011). They are habitats for ecologically

Communicated by Anne Bousquet-Melou

Johann Stiepani

johann.stiepani@geo.uu.se

1 Department of Biogeography, University of Bayreuth, Universitätsstrasse 30, 95447 Bayreuth, Germany

2 Leibniz Centre for Tropical Marine Research (ZMT), Fahrenheitstraße 6, 28359 Bremen, Germany

3 Natural Resources and Sustainable Development, NRHU Department of Earth Sciences, Uppsala University, Campus Gotland, Visby, Sweden

4 Centre for Marine and Coastal Studies, Universiti Sains Malaysia, Gelugor, 11800 Penang, Malaysia important benthic macro-invertebrates that contribute to the functionality of the coastal ecosystem and even influence the pelagic food chain (Ellison 2008; Nagelkerken et al. 2008; Vermeiren et al. 2015). In the majority of mangrove forests, brachyuran or "true crabs" dominate macro-invertebrates in terms of biomass and density (Kristensen 2008; Lee 2008; Nordhaus et al. 2009). Considering only Asia, Malaysia hosts the second largest mangrove forest in terms of area $(641,886$ ha), second only to Indonesia (Spalding et al. 2010). Malaysia is located within the Indo-West Pacific (IWP), a biogeographic region of tropical waters expanding from the Indian Ocean to Pacific Ocean. The IWP has 6-7 times more mangrove tree species compared to the Atlantic Caribbean East Pacific (Ricklefs and Latham 1993; Ricklefs et al. 2006; Hinrichs et al. 2009). Additionally, the IWP is considered a biodiversity hotspot for mangrove crabs as shown for Indonesia (Nordhaus et al. 2009; Geist et al. 2012), Brunei Darussalam (Ribero et al. 2020), and Malaysia (Ribero et al. 2019).

Macro-invertebrates, specifically the ubiquitous crabs, are important to the health and functionality of mangrove forests 
(Ellison 2008). These decapods are considered ecosystem engineers that modify, maintain, or destroy their physical environment (Jones 1984; Lee 1998; Wright and Jones 2006; Kristensen and Alongi 2006). Globally, the adaptive radiation of crabs has been thoroughly investigated with 6793 described species from 93 different taxonomic families (Lee 1998; Ng et al. 2008; Nordhaus et al. 2009). Within the IWP, two superfamilies Grapsoidea and Ocypodoidea are predominant in mangrove crab populations (Lee 1998; Nordhaus et al. 2009). In Peninsular Malaysia, over 350 crab species have been documented of which 62 species are adapted to life in the mangrove (Tan and Ng 1994).

Regarding their feeding habit, mangrove crabs form several functional groups in the mangrove forest (Geist et al. 2012). Sesarmid crabs are mainly leaf litter feeders but have been observed to exhibit omnivorous and scavenging behaviors (Kristensen 2008). In contrast, Ocypodoidea are sediment filters that sustain on the microphytobenthos in the sediment (Crane 1975; Kristensen 2008). Both, sesarmid and ocypodid crabs, link primary production to the higher trophic levels of the mangrove forest (Alongi 2002; Kristensen and Alongi 2006; Kristensen 2008). Besides adding to the trophic cascade, crab activities such as leaf burial promote microbial heterogeneity and conservation of nutrients in the sediment (Robertson 1986; Ashton 2002; Kristensen 2008). Crab burrowing changes the biogeochemical processes including redox condition, sediment aeration, and carbon cycling and promotes heavy metal partitioning in the sediment which are important regulatory services provided by crabs to the mangrove (Kristensen 2008; Pülmanns et al. 2014).

Often the biophysical structure of a mangrove forest is correlated to brachyuran crab assemblages (Lee 1998; Ashton et al. 2003; Ribero et al. 2019). Dominances of certain brachyuran crabs in the community can indicate the current and past health of a mangrove forest (Macintosh et al. 2002; Ashton et al. 2003). High abundances of grapsid crabs are associated with old growth mangrove forests of Malaysia and Thailand (Macintosh et al. 2002; Ashton et al. 2003), while high abundances of ocypodid crabs are associated with recently disturbed or young mangrove forests (Macintosh 1984; Sasekumar and Chong 1998; Macintosh et al. 2002). In the IWP, the monitoring of brachyuran crab for shifts in community structure can be a useful tool to gain insight on the ecological health of a mangrove forest (Macintosh et al. 2002; Ashton et al. 2003).

Urban development is considered a driver for the lost and fragmentation of mangrove forests (Alongi 2002; Friess et al. 2012; Branoff 2017). Although mangrove loss is projected to continue into the future, little research has focused on the implications of urbanization to the biodiversity within mangrove forests. This study aims to determine the current biodiversity of mangrove vegetation and crab assemblages of Penang, Malaysia. Furthermore, we aim to investigate the impacts of urbanization onto mangrove forest structure, mangrove crab assemblages, and abiotic conditions by comparing urban and rural study sites. Finally, we aim to determine specific land use types, abiotic factors, and tree abundances which are the most explanatory to the mangrove crab assemblages of Penang, Malaysia.

\section{Materials and methods}

\section{Study site}

The study was carried out in mangrove systems located across Penang, Malaysia $\left(5.4141^{\circ} \mathrm{N}, 100.3288^{\circ} \mathrm{E}\right)$ (Fig. 1). In terms of area, Malaysia covers $328,657 \mathrm{~km}^{2}$ of land and has a $4675 \mathrm{~km}$ coastline. Penang, Malaysia, is a highly urbanized coastal municipality on the Strait of Malacca (Department of Statistics Malaysia 2015; Chee et al. 2017). Penang boasts a population of 1.7 million people with a population density of 1663 people $\mathrm{km}^{-2}$, the highest population density of a Malaysian city outside of the capital Kuala Lumpur (Department of Statistics Malaysia 2015). In total, 37\% of Penang Island's land area is considered urbanized (Chee et al. 2017). Mangrove forests are found in both urban and rural coastlines of Penang (Chee et al. 2017). Eastern portions of Penang are highly urbanized, while the western portions of the island are covered by agriculture, natural vegetation, and small human settlements (Mohammed et al. 2015; Chee et al. 2017). Located on Peninsular Malaysia, Penang consists of an island and mainland portion with a total area of $1048 \mathrm{~km}^{2}$. To the north of Penang lays Thailand $(120 \mathrm{~km})$, and across the Strait of Malacca to the west lays the Sumatra Island of Indonesia $(150 \mathrm{~km})$. Penang has a tropical climate with a wet season from March to November. Fieldwork was conducted during the months from June 2017 until August 2017. During the time period of this study, Malaysia was impacted by the southwest monsoon although during the first month of the study June 2017 an atypically low rainfall of $47.2 \mathrm{~mm}$ was recorded (Malaysian Meteorological Department 2017). In two consecutive months of the study, heavy rains occurred $150 \mathrm{~mm}$ in July and $160 \mathrm{~mm}$ in August (Malaysian Meteorological Department 2017). In total, six sites were selected for fieldwork; three urban and three rural sites. The three rural sites were Balik Pulau $\left(5.4129^{\circ} \mathrm{N}\right.$, $\left.100.4412^{\circ} \mathrm{E}\right)$, Permatang Pasir or Pantai Acheh $\left(5.4129^{\circ} \mathrm{N}\right.$, $\left.100.4412^{\circ} \mathrm{E}\right)$, and Teluk Ayer Tawar $\left(5.4825^{\circ} \mathrm{N}, 100.3851^{\circ}\right.$ E) (Fig. 1). The three urban sites were Free Trade Zone $\left(5.2945^{\circ} \mathrm{N}, 100.2593^{\circ} \mathrm{E}\right)$, Jelutong $\left(5.3950^{\circ} \mathrm{N}, 100.3105^{\circ}\right.$ E), and Sungai Sembilang $\left(5.3655^{\circ} \mathrm{N}, 100.4590^{\circ} \mathrm{E}\right)$ (Fig. 1). Four of the study sites Balik Pulau, Permatang Pasir, Free Trade Zone, and Jelutong are located on the island of Penang, while the remaining two study sites Teluk Ayer 

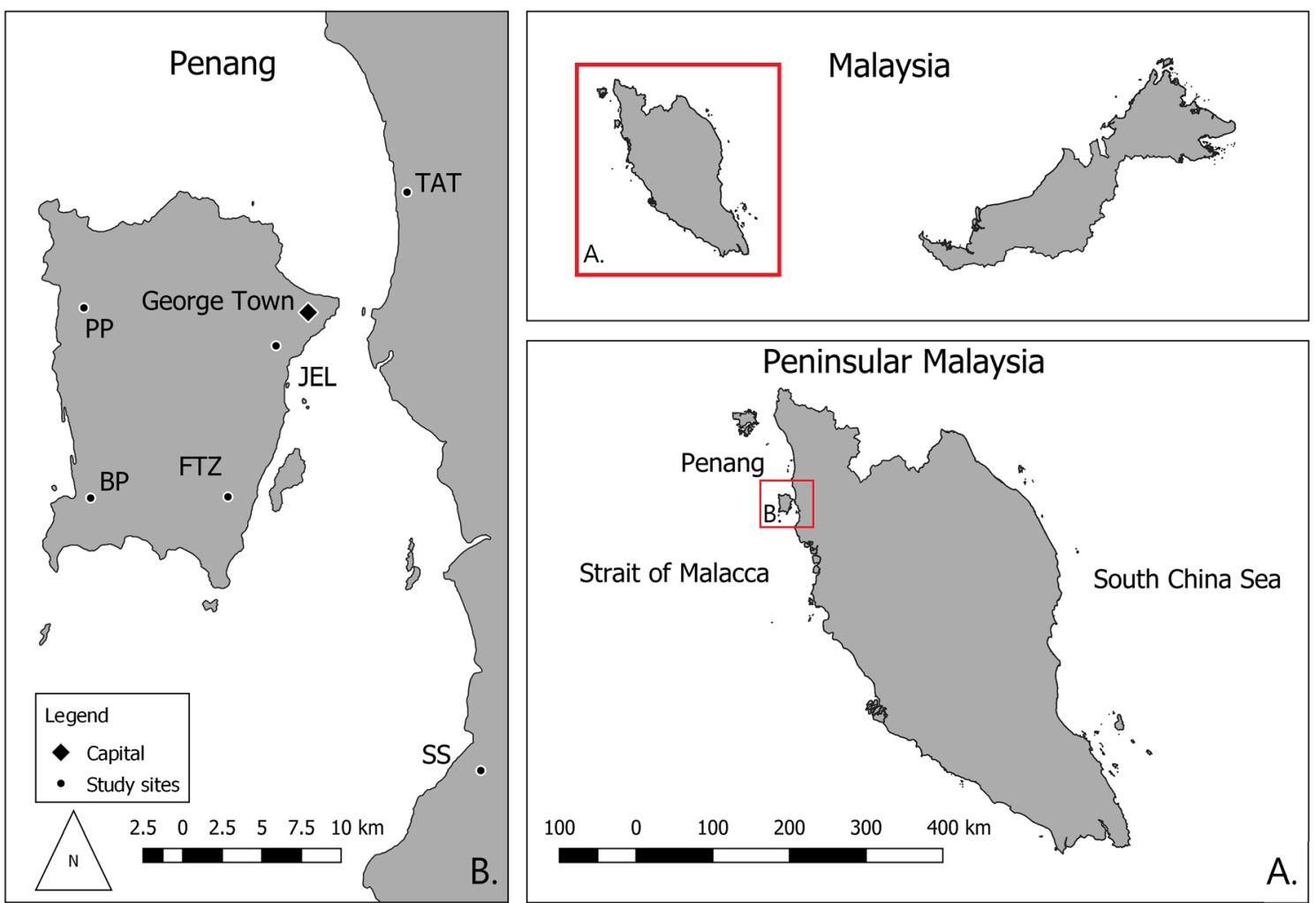

Fig. 1 Location of six sampling sites in Penang, Malaysia. The island of Penang is located in Peninsular Malaysia. Abbreviation for study sites are BP, Balik Pulau; PPB, Permatang Pasir; TAT, Teluk Ayer Tawar; FTZ, Free Trade Zone; JEL, Jelutong; and SS, Sungai Sembilang

Tawar and Sungai Sembilang are located on the western coastline of Peninsular Malaysia.

\section{Mangrove vegetation collection}

Vegetation data was collected within $1210 \mathrm{~m} \times 10 \mathrm{~m}$ quadrats $\left(100 \mathrm{~m}^{2}\right)$ at each study sites. The design of the vegetation sampling was to collect data along the tidal gradient with three transect rows. Collection quadrats were portable and a measuring tape was used for consistency in quadrat size. The first transect row was set on the "fringe" or the most seaward portion of the mangrove forest. The second transect row was placed 25-m inland from the first transect row. Finally, a third transect row was placed 25-m inland from the second transect row. Data collection was modified at urban areas sites JEL and FTZ due to small mangrove forest extent. Therefore, the 12 quadrats at JEL and FTZ were all placed in one transect row parallel to the coast. Within each quadrat, all mangrove tree species and understory species were recorded and identified to the genus level. Several of the mangrove tree species were difficult to distinguish at the species level (these trees were given the abbreviation sp. after the genus name). At the center of each quadrat, the coordinates were recorded using a Garmin GPS eTrex 10.
Tree height was used to differentiate adult trees from juvenile trees. All trees above $1.3 \mathrm{~m}$ were considered adults. Juvenile trees were separated into two further groups: saplings and seedlings. All trees below $0.025-\mathrm{m}$ height were recorded as seedlings (Hinrichs et al. 2009) and trees between the heights of 0.025 and $1.3 \mathrm{~m}$ were considered saplings (English et al. 1994). For juveniles, trees height was recorded and a DBH of $1 \mathrm{~cm}$ was used for consistency (English et al. 1994). For adult trees, girth at breast height (GBH) was recorded at the height of $1.3 \mathrm{~m}$. When the stem of a tree species had a prop roots or fluted lower trunk (Rhizophora spp.), DBH was measured $20 \mathrm{~cm}$ above the root collar (English et al. 1994). Girth was converted to diameter at breast height $(\mathrm{DBH}, \mathrm{DBH}=\mathrm{GBH} / \pi)$ which was then used to calculate basal area (BA, BA $=\pi$ * $\left.\mathrm{DBH}^{2} / 4\right)$. Stand basal area (SBA) was calculated as the sum of all BA at each site (in $\mathrm{cm}^{2} \mathrm{~m}^{-2}$ ).

All vegetation types were recorded in each $100-\mathrm{m}^{2}$ plot to calculate density for each species present. Understory vegetation was measured in terms of percentage covered in each $100-\mathrm{m}^{2}$ plot, which was recorded by increments of $10 \%$. Mangrove vegetation and understory plants were identified by visual analysis of leaves, flowers, propagules, bark, and fruits using various mangrove identification manuals (Kitamura et al. 1997, Giesen et al. 2007, Primavera et al. 
2004, and FAO 2007). For species, which were difficult to identify in the field, samples of propagules and flowers were brought back to the laboratory for identification. It should be noted that no photos were taken of the vegetation for further records.

\section{Brachyuran crab collection}

Within each $100-\mathrm{m}^{2}$ vegetation quadrat, one $0.72 \mathrm{~m}^{2}$ quadrat (length of each edge was $0.85 \mathrm{~m}$ ) was placed at the epicenter for collection of brachyuran crabs. Four plastic barriers with the dimensions of $0.85 \mathrm{~m}$ (length) $\times 0.20 \mathrm{~m}$ (height) prevented crabs from escaping the quadrat. In the $0.72-\mathrm{m}^{2}$ quadrat, all crabs were collected by hand and brought back to the lab for identification, weighing, and measuring. To ensure all crabs were captured, burrows were excavated mainly using hand although shovels and spoons were also used to dig to the estimated depth of $0.5 \mathrm{~m}$. When crab burrows were observed in a quadrat, each burrow was excavated to collect all crabs present. After the initial collection of crabs, the plot was observed for a 10-min period to ensure all crabs were collected. Crabs were identified using identification manuals (Serène and Soh 1967; 1970; Crane 1975; Tan and Ng 1994; Davie 1992; 1994; 2003; Davie and Pabriks 2010). After identification, crabs were weighed (wet mass) to the nearest hundredth of a gram. Carapace lengths and widths were taken to the nearest millimeter. Crabs were gendered based on the shape of their pleon. Three male specimens of each species were captured during fieldwork and then later preserved and placed in the specimen reference library at Center for Marine and Coastal Studies (CEMACS) in Penang, Malaysia.

\section{Abiotic parameters collection}

Abiotic factors were measured during the field survey at each quadrat prior to crab collection. Water samples were taken from the burrows of the crabs at $0.2 \mathrm{~m}$ below surface within the $0.72-\mathrm{m}^{2}$ quadrat. Salinity was tested using a handheld Refractometer Salinity Test (Marine Reef Hydrometer). A Hanna HI9147 meter measured the dissolved oxygen content $\left(\mathrm{mg} \mathrm{l}^{-1}\right.$ ) and temperature $\left({ }^{\circ} \mathrm{C}\right)$. The $\mathrm{pH}$ was tested with a $\mathrm{pH}$ plus Pal+ (trans instrument). Waste coverage on the mangrove forest floor was recorded as an additional abiotic factor. At each $100-\mathrm{m}^{2}$ vegetation quadrat, percentage of waste covering the substrate was recorded by integrals of ten; $0 \%$ indicating no waste, while $100 \%$ indicating full coverage of the quadrat. Substrate type was recorded at each quadrat by visual observation. A rating scale to grade (from 1 to 4 ) was used to indicate different grain sizes of substrate. The lowest score of 1 indicates the smallest substrate particles (watery mud), 2 indicates firm mud, 3 indicates a mixture of sand and pebble substrate, while the highest value of 4 indicates large particles (rocks and stones).

\section{Classification of mangrove catchment area}

The borders of the catchment area of each study site were delineated in Google Earth Pro v.7.3.1, with the digital elevation data from the area. Using Landsat and Copernicus satellite imagery, the land use in the catchment areas was classified as mangrove forest, natural forest, agriculture, shrimp farms, and cleared and urban areas. Areas for these land use were then calculated in Google Earth Pro v.7.3.1. Study sites were classified as urban if $50 \%$ or more of the total land area was urban or industry combined. Rural sites were classified if 50\% or more of the total area was mangrove forest, non-mangrove forest, or agriculture combined.

\section{Data analyses}

All analyses were completed using STATISTICA 13.0, R 3.4.3, and PAST 3.18. The Levene test was used to check for homoscedasticity, and the Shapiro-Wilk test was used to check for normality in distribution of data. In case of homoscedasticity and normality of the data, a t-test was used; otherwise, the non-parametric Mann-Whitney U test was performed to compare urban and rural sites. For crab abundance, biomass, and mangrove tree abundance data, total number of species (S), Shannon's index (H') (Shannon 1948), Simpson's index (1- $\lambda$ ) (Simpson 1949), Margalef's index (d) (Margalef 1958), and Pielou's evenness (J) (Pielou 1966) were calculated for urban, rural, and considering all sites in the study. Species importance (IV) (English et al.1994) was calculated for each mangrove tree species to identify structural importance of each species. IV includes density (density of a species / total species density $\times 100$ ), basal area (BA of one species / SBA $\times 100$ ), and frequency (frequency of one species / total species frequency $\times 100$ ). The sum of the IV of all species in a forest stand is 300 .

A 1-way ANOSIM was conducted to compare IV of mangrove forest species between urban and rural sites. Five separate SIMPER tests (similarity percentage analysis) were conducted to investigate forest structure (based on IV), crab biomass, crab density, abiotic features, and classification of land use data between urban and rural sites. Redundancy analysis (RDA) was performed to crab abundance data using potential explanatory variables, consisting of all abiotic parameters, tree abundance data, and land use data. The final explanatory variables for the RDA model were selected using a forward selection eliminating the variables abiotic, tree abundance data, land use, and those land use types that had higher than 10 variance inflation factors (VIF). 


\section{Results}

\section{Mangrove tree species abundance, diversity, and regeneration}

In total, 5853 trees were recorded including 15 species from six different mangrove families including Acanthaceae, Arecaceae, Lythraceae, Malvaceae, Meliaceae, and Rhizophoraceae (Table 1). Avicennia marina was the most abundant tree in the mangrove of Penang with 4865 individuals recorded, constituting $82.6 \%$ of all trees in this study. The remaining $17.6 \%$ (988) of tree abundance was composed of $4.6 \%$ (271) from Nypa fruticans, 4.2\% (250) from Rhizophora apiculata, 2.4\% (142) from Rhizophora mucronata, and $1.6 \%$ (94) from Avicennia alba, while the remaining ten species contributed less than $1 \%$ to the total tree abundance within the study (Table 1).

Of the 5853 trees recorded only 3341 were considered adult trees. In total, $43.2 \%$ (2544) of the mangrove trees were categorized as juvenile $(<1.3 \mathrm{~m})$ showing a high regeneration within the mangrove forest of Penang. The size composition of juveniles consisted of $44.6 \%$ (1137) mangrove saplings (> $0.025 \mathrm{~m})$ and $55.3 \%$ (1407) seedlings $(<0.025 \mathrm{~m})$. The majority of mangrove seedlings recorded in the mangrove forest of Penang were A. marina (96\%). No significant difference was found between urban and rural mangrove seedling compositions, but the highest density of seedlings was observed in the rural site BP with 685 seedlings ( $48.7 \%$ of all seedlings in the study). A. marina had the highest diameter at breast height $(\mathrm{DBH})$ of $63.03 \mathrm{~cm}$ in the study. Three other species were found with similar DBH including Avicennia alba (60.48 $\mathrm{cm})$, Rhizophora mucronata $(61.43 \mathrm{~cm})$, and Rhizophora spp. $(60.78 \mathrm{~cm})$. Two understory species, Acanthus volubilis and Acrostichum speciosum, were found at the urban site of SS in low densities (Table 1).

\section{Spatial variability: comparing rural and urban forest structure}

A significantly higher number of tree species was observed in urban than in rural sites (Mann-Whitney $\mathrm{U}$ test, $\mathrm{U}=410.5$, $\mathrm{p}=$ 0.007). Total number of mangrove tree species was higher at SS (11), FTZ (8), and BP (6), while the remaining sites had lower species richness TAT (2), PPB (3), and JEL (4). Considering the entire study, there were 15 tree species recorded with 13 trees species recorded in urban sites and seven tree species recorded in rural sites. Tree abundance at urban sites reported a higher $\mathrm{S}, \mathrm{d}, \mathrm{H}^{\prime}, \mathrm{J}$, and $1-\lambda$ when compared to rural sites (Table 3).

A. marina was the most abundant tree species recorded in this study. Of the 4865 A. marina trees recorded 3909 (80.3\%) were found at rural study sites and the remaining 956 (19.7\%) at urban study sites. The stand basal area (SBA) of A. marina was $10.03 \pm 9.6 \mathrm{~cm} \mathrm{~m}^{-2}$ which was the highest SBA of any species in this study. The SBA of Avicennia alba was $1.89 \pm$ $4.63 \mathrm{~cm} \mathrm{~m}^{-2}$, the SBA of Rhizophora apiculata was $2.25 \pm$

species and ground coverage in percentage for understory vegetation are presented for all sites in the study
Table 1 Species importance (IV) and stand basal area (SBA) with standard deviations of mangrove tree species considering all sites (total) in study, then rural, and urban sites separately. Total tree abundance per

\begin{tabular}{|c|c|c|c|c|c|c|}
\hline Family & Species & Total IV & Rural IV & Urban IV & $\operatorname{SBA}\left(\mathrm{cm} \mathrm{m}^{-2}\right)$ & Total tree abundance \\
\hline \multirow[t]{3}{*}{ Acanthaceae } & Avicennia alba & 17.3 & 0 & 24.4 & $1.89 \pm 4.63$ & 94 \\
\hline & Avicennia marina & 184.9 & 234.8 & 111.8 & $10.03 \pm 9.63$ & 4,865 \\
\hline & Avicennia officinalis & 5.7 & 8.4 & 8.8 & $0.20 \pm 0.32$ & 20 \\
\hline Malvaceae & Talipariti tiliaceum & 1.3 & 0 & 3.9 & $0.27 \pm 0.61$ & 3 \\
\hline Meliaceae & Xylocarpus granatum & 2.7 & 0 & 5.8 & $0.41 \pm 0.99$ & 7 \\
\hline Arecaceae & Nypa fruticans & 13.1 & 4.3 & 37.9 & $0.32 \pm 0.75$ & 271 \\
\hline \multirow[t]{6}{*}{ Rhizophoraceae } & Bruguiera cylindrica & 4.1 & 18.5 & 0 & $0.20 \pm 0.35$ & 68 \\
\hline & Bruguiera gymnorrhiza & 5.2 & 0 & 9.57 & $0.55 \pm 1.34$ & 49 \\
\hline & Ceriops tagal & 3.8 & 0 & 6.77 & $0.20 \pm 0.48$ & 44 \\
\hline & Rhizophora apiculata & 24.1 & 7.4 & 39.03 & $2.25 \pm 4.91$ & 250 \\
\hline & Rhizophora mucronata & 22.9 & 13.3 & 20.95 & $0.50 \pm 1.22$ & 142 \\
\hline & Rhizophora sp. & 1.8 & 0 & 4.96 & $0.86 \pm 0.99$ & 12 \\
\hline \multirow[t]{4}{*}{ Lythraceae } & Sonneratia alba & 11 & 13.3 & 16.53 & $0.82 \pm 1.46$ & 24 \\
\hline & Sonneratia caseolaris & 1.4 & 0 & 1.42 & $0.06 \pm 0.14$ & 2 \\
\hline & Sonneratia ovata & 0.7 & 0 & 8.23 & $0.03 \pm 0.65$ & 2 \\
\hline & Understory vegetation & & & & & $\%$ coverage \\
\hline Acanthaceae & Acanthus volubilis & & & & & 0.0013 \\
\hline Pteridaceae & Acrostichum speciosum & & & & & $0.002 \pm 0.0009$ \\
\hline
\end{tabular}


$4.91 \mathrm{~cm} \mathrm{~m}^{-2}$, and the SBAs of the remaining 12 tree species were low (Table 1). The SBA of A. marina did not differ significantly between urban and rural sites (Mann-Whitney $\mathrm{U}$ test, $\mathrm{U}=3, \mathrm{p}=0.663$ ). The trend for nonsignificant variation of SBA between urban and rural sites remained true for all mangrove tree species in the study.

For the entire study, A. marina contributed the most to species importance (IV) with 184.9 (Table 1). The remaining tree species had considerably smaller IV values in comparison to A. marina. While only considering rural sites, A. marina again had the highest contribution to IV with a value of 234.8 , whereas no other species contributed a IV score higher than 20 (Table 1). For urban sites, A. marina again contributed the highest to IV score with 111.80 , but a lower IV compared to rural sites. At urban sites, other species that contributed to IV were $R$. apiculata (39.03), N. fruticans (37.9), A. alba (24.4), and $R$. mucronata (20.95), and all other ten species contributed less than 20 to the IV (Table 1). Species importance (IV) for mangrove trees did not differ significantly between urban and rural forests ( 1 -way ANOSIM, $r=0.3707, p=0.104$ ).

\section{Brachyuran community composition}

Crabs collected from Penang represent three superfamilies: Grapsoidea (6 species), Ocypodoidea (6 species), and Paguroidea ( 1 species) (Table 2). In total, 633 crabs were recorded in 72 quadrats. The mean average density of all brachyuran crabs was 10.9 crabs $^{-2}$ and mean biomass was $26.0 \mathrm{~g} \mathrm{~m}^{-2}$. In this study, $51.8 \%$ of all crabs were male and the remaining $48.2 \%$ were female. Of the female population, $18 \%$ were ovigerous at the time of capture. The largest crab individual was a female Episesarma versicolor at site PPB with the mass of $23.86 \mathrm{~g}$ and the dimension of $3.36-\mathrm{cm}$ width and $2.98-\mathrm{cm}$ length with no eggs. The average mass for E. versicolor was $9.29 \pm 3.63 \mathrm{~g}$ with a width of $2.34 \pm$ $0.66 \mathrm{~cm}$ and a length of $2.11 \pm 0.58 \mathrm{~cm}$. In comparison, the smallest crab found was a female Ilyogynnis microcheirum with the mass of $0.012 \mathrm{~g}$ and the dimensions of $0.75-\mathrm{cm}$ width and $0.58-\mathrm{cm}$ length with no eggs. The average mass for I. microcheirum was $0.17 \pm 0.30 \mathrm{~g}$ with the average width of $0.37 \pm 0.18 \mathrm{~cm}$ and average length of $0.30 \pm 0.15 \mathrm{~cm}$. Superfamily Grapsoidea had twice the abundance and four times the biomass of the Ocypodoidea.

\section{Comparison of crab densities, biomass, and diversity between urban and rural sites}

The total number of crab species encountered in the study was 13 (Fig. 2). Both, urban and rural sites had 12 crab species. The total number of crab species varied between sites (PP 9, TAT 7, BP 6, FTZ 9, JEL 5, SS 9). For both crab abundance and biomass, there was higher H' and $\mathrm{J}$ at urban sites in comparison to rural study sites (Table 3). Species richness (d) was equal at both urban and rural study sites (Table 3). For crab abundance, $1-\lambda$ was higher at urban study sites, while for crab biomass $1-\lambda$ was higher at rural study sites (Table 3). Only four crab species including Parasesarma longicristatum, Parasesarma eumolpe, Tubuca paradussumieri, and I. microcheirum densities varied significantly between rural to urban sites (Table 2, Supplementary data 1). On the other hand, the biomasses of five crab species including P. longicristatum, P. eumolpe, T. paradussumieri, Tubuca rosea, and I. microcheirum varied significantly between urban and rural sites (Table 2, Supplementary data). $P$. longicristatum contributed the most to differences in crab densities (46.33\%, SIMPER test) and to biomass of crabs (21.86\%, SIMPER test) when comparing crab communities between urban and rural sites. P. eumolpe contributed the second most to differences between crab biomass (13.27\%, SIMPER test) and the third most to crab densities $(8.49 \%$, SIMPER test), while T. paradussumieri contributed the second most (9.0\%, SIMPER test) to dissimilarity in crab densities for urban and rural sites. All other crab species contributed less to the dissimilarity in crab density and biomass between urban and rural study sites (Table 2, Supplementary data).

\section{Abiotic data analyses}

Only three abiotic variables including waste $(\mathrm{p}<0.001)$, DO $(\mathrm{p}<0.05)$, and salinity $(\mathrm{p}<0.001)$ varied significantly in Mann-Whitney U tests, while substrate type, temperature, and $\mathrm{pH}$ did not vary significantly between urban and rural sites (Table 4). Considering all abiotic factors, waste contributed $92.1 \%$ to the differences in variance between urban and rural sites (SIMPER test). The factors salinity, $\mathrm{pH}$, dissolved oxygen, substrate, and temperature contributed less than $10 \%$ to the difference between urban and rural sites (SIMPER test).

\section{Land use data}

Three land use areas varied significantly (Mann-Whitney U test) between urban and rural sites including agricultural $(\mathrm{p}<$ $0.001)$, industrial $(\mathrm{p}<0.001)$, and urbanized areas $(\mathrm{p}<0.001)$ (Supplementary data). The remaining four land use areas including mangrove forests, non-mangrove forests, cleared areas, and shrimp ponds did not vary significantly between urban and rural sites (Supplementary data). Agriculture contributed $35.10 \%$ to this difference and industry $18.55 \%$ (SIMPER test). All other land use types contributed less than $15 \%$ to difference between urban and rural sites (SIMPER test). Mangrove forest area contributed $22.07 \%$ and $12.91 \%$ to the total catchment area at urban and rural sites, respectively (Supplementary data). 
Table 2 Lists of all crab species found in the study and significant differences for crab densities (crabs/meter ${ }^{2}$ ) and biomass (grams) between urban and rural study sites. Significant differences are given as $* p<0.05$,
$* * \mathrm{p}<0.01$, and $* * * \mathrm{p}<0.001$ (Mann-Whitney U test). SIMPER results showing average dissimilarity (Av Diss) in percent of crab density and biomass between urban and rural sites

\begin{tabular}{|c|c|c|c|c|c|c|c|}
\hline \multirow[b]{2}{*}{ Family } & \multirow[b]{2}{*}{ Species } & \multicolumn{2}{|l|}{ Density } & \multirow[b]{2}{*}{ Av diss } & \multicolumn{2}{|l|}{ Biomass } & \multirow[b]{2}{*}{ Av diss } \\
\hline & & Rural & Urban & & Rural & Urban & \\
\hline Grapsidae & Metopograpsus frontalis (Miers 1880) & 0 & $0.15 \pm 0.70$ & 0.59 & 0 & $0.15 \pm 0.68$ & 1.14 \\
\hline Grapsidae & Episesarma mederi (A. Milnes Edwards 1853) & $0.85 \pm 2.04$ & $0.87 \pm 2.14$ & 6.64 & $2.70 \pm 6.62$ & $0.79 \pm 2.16$ & 7.90 \\
\hline Sesarmidae & Episesarma versicolor (Tweedie, 1940) & $0.31 \pm 0.88$ & $0.42 \pm 1.04$ & 5.98 & $2.50 \pm 10.88$ & $2.0 \pm 6.22$ & 3.13 \\
\hline Sesarmidae & Parasesarma eumolpe (De Mann 1895) & $0.81 \pm 1.67 * * *$ & $2.96 \pm 4.28 * * *$ & 8.49 & $1.68 \pm 3.48 * *$ & $3.08 \pm 5.01 * *$ & 13.27 \\
\hline Sesarmidae & Parasesarma longicristatum (Campbell 1967) & $5.01 \pm 5.38 * * *$ & $1.49 \pm 2.68 * * *$ & 46.33 & $24.96 \pm 22.84 * *$ & $2.60 \pm 5.80 * *$ & 21.86 \\
\hline Varunidae & Metaplax elegans (De Mann 1888) & $0.018 \pm 0.47$ & $0.73 \pm 2.31$ & 2.31 & $0.09 \pm 0.51$ & $1.11 \pm 3.63$ & 3.11 \\
\hline Camptandriidae & Baruna trigranulum (Dai \& Song 1986) & $0.04 \pm 0.24$ & $0.07 \pm 0.45$ & 0.52 & $0.02 \pm 0.12$ & $0.04 \pm 0.19$ & 0.60 \\
\hline Camptandriidae & Ilyogynnis microcheirum (Tweedie 1937) & $0.73 \pm 1.75 * * *$ & $2.91 \pm 3.69 * * *$ & 2.10 & $0.13 \pm 0.33 *$ & $0.35 \pm 0.49 *$ & 13.11 \\
\hline Camptandriidae & Paracleistostoma depressum (De Mann 1895) & $0.33 \pm 1.13$ & $0.98 \pm 3.46$ & 1.47 & $0.10 \pm 0.40$ & $0.38 \pm 1.26$ & 4.62 \\
\hline Ocypodidae & Tubuca rosea (Tweedie 1937) & $1.18 \pm 2.51$ & $0.73 \pm 1.57$ & 4.48 & $2.29 \pm 5.19 * *$ & $0.47 \pm 1.19^{* *}$ & 7.97 \\
\hline Ocypodidae & Tubuca paradussumieri (Bott 1973) & $0.73 \pm 2.16^{*}$ & $0 *$ & 9.04 & $6.59 \pm 19.30^{*}$ & $0 *$ & 4.29 \\
\hline Ocypodidae & Austruca triangularis (A. Milne Edwards 1873) & $0.81 \pm 2.73$ & $0.47 \pm 1.22$ & 1.48 & $0.18 \pm 0.66$ & $0.12 \pm 0.36$ & 4.57 \\
\hline Coenobitidae & Coenobita lila (Shih \& Ng 2016) & $0.08 \pm 0.33$ & $0.22 \pm 0.99$ & 2.44 & $0.85 \pm 4.43$ & $0.37 \pm 1.64$ & 0.93 \\
\hline
\end{tabular}

\section{Redundancy analysis}

The RDA (Fig. 3) explained $32.7 \%$ of biological variability of the crab assemblages. After the forward selecting process of the RDA, all abiotic factors that had variance inflation factors (VIF) higher than the threshold of ten were removed from the RDA model (Table 5). The constrained inertia was $40 \%$ for the RDA. RDA 1 and RDA 2 explained $69 \%$ of the constrained variation. RDA axes 1-3 were highly significant (smallest $\mathrm{p}<0.002$ ). For the whole RDA, the total residuals were $59(\mathrm{DF}=7, \mathrm{~F}=5.58$, and $\mathrm{p}>0.001)$.

\section{Discussion}

Mangrove flora recorded in this study consisted of six genera with 15 different mangrove tree species and two understory shrubs. The Indo-West Pacific (IWP) is known to have the highest mangrove diversity on Earth with at least 69 mangrove species (Saenger et al. 2019), while this study of Penang, Malaysia, found a relatively low number of tree species. Considering all mangrove forests in this study, a high abundance of A. marina resulted in a low Shannon index, low species richness, and low evenness among tree species (Table 3). One feature of urban mangroves in Penang was high Shannon's index, high species richness, and high evenness among tree species compared to rural mangrove forests (Table 3).

Considering the whole Indo-Malaysian region, the investigated mangrove forests of Penang recorded a relatively low number of tree species. Yet, the number of mangrove tree species reported in Penang was comparable to other studies from Peninsular Malaysia. Klang Island Mangrove Forest Reserves, Selangor, Malaysia, reported 10 species from three families (Rhizophoraceae, Acanthaceae, and Meliaceae); a second study of Matang Mangrove Forest Reserve, Malaysia, reported eight mangrove species from three families (Rhizophoraceae, Acanthaceae, and Euphorbiaceae), and a

Table 3 Diversity measures of mangrove crabs for abundance and biomass (grams) and mangrove tree abundance. The table shows total number of species (S), Margalef's index (d), Shannon's index (H'), Pielou's evenness (J), and Simpson's index (1- $\lambda$ ) for urban, rural, and all study sites

\begin{tabular}{|c|c|c|c|c|c|c|c|c|c|c|c|c|c|}
\hline \multicolumn{6}{|c|}{ Crab abundance } & \multicolumn{3}{|c|}{ Crab biomass } & \multicolumn{5}{|c|}{ Tree abundance } \\
\hline & $\mathrm{S}$ & $\mathrm{d}$ & $\mathrm{H}^{\prime}$ & $\mathrm{J}$ & $1-\lambda$ & $\mathrm{H}^{\prime}$ & $\mathrm{J}$ & $1-\lambda$ & S & $\mathrm{d}$ & $\mathrm{H}^{\prime}$ & $\mathrm{J}$ & $1-\lambda$ \\
\hline All sites & 13 & 1.86 & 2.09 & 0.62 & 0.83 & 1.89 & 0.51 & 0.73 & 14 & 1.73 & 0.67 & 0.25 & 0.31 \\
\hline Urban & 12 & 1.91 & 2.08 & 0.66 & 0.71 & 2.06 & 0.66 & 0.85 & 13 & 1.73 & 1.43 & 0.52 & 0.68 \\
\hline Rural & 12 & 1.91 & 1.72 & 0.47 & 0.83 & 1.56 & 0.39 & 0.61 & 7 & 0.84 & 0.25 & 0.10 & 0.07 \\
\hline
\end{tabular}




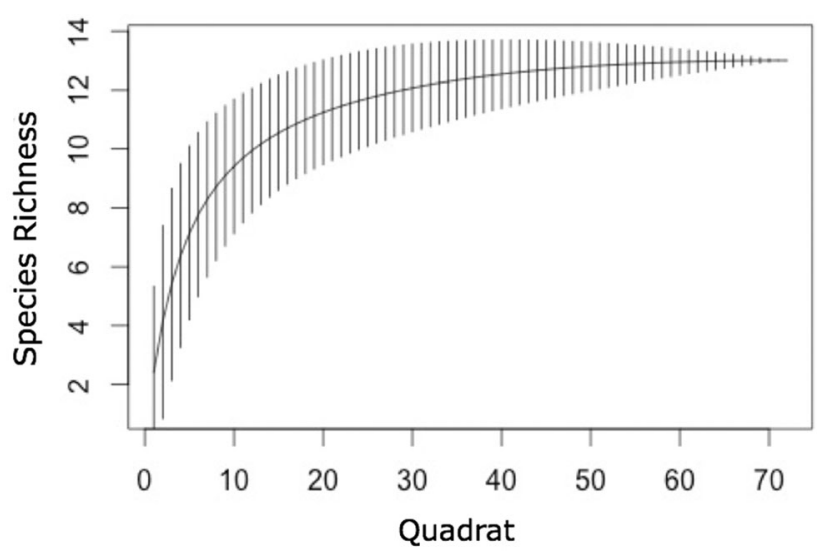

Fig. 2 Species accumulation curve including standard deviation in each quadrat for brachyuran crabs of Penang, Malaysia

third study of Langkawi, Malaysia, found three mangrove species from one family (Rhizophoraceae) (Norhayati et al. 2009; Hookham et al. 2014; Goessens et al. 2014). The number of mangrove tree species found in Penang was higher than in Klang, Matang, and Langkawi which are located in Peninsular Malaysia and less than $200 \mathrm{~km}$ away from the municipality of Penang. Lower collection replications, differences in quadrat size, and differences in forest management could be the reason for different number of tree species recorded in the other studies (Jusoff and Taha 2008; Norhayati et al. 2009; Goessens et al. 2014; Hookham et al. 2014). At the Matang Mangrove Forest Reserve, human influence through a sustainable yield production program should be noted. A part of the managed plan is a 30 -year rotating cycle, which may reduce the ability of new species to establish in the Matang Mangrove Forest Reserve (Jusoff and Taha 2008). In Langkawi, mangroves have been replanted in a sustainable yet monoculture fashion to promote the growth of the economically valuable species Rhizophora spp., neglecting natural succession of the mangrove forests (Hookham et al. 2014). While in the recent history of Penang, land reclamation has added new grounds for mangrove establishment increasing total mangrove forest in urban areas (Chee et al. 2017).
Table 5 Biplot values for the RDA model are provided including DF (degrees of freedom), AIC (Akaike information criterion), F (F-value), and $\mathrm{p}$-values

\begin{tabular}{lllll}
\hline Factor & DF & AIC & F & $\begin{array}{l}\text { p- } \\
\text { value }\end{array}$ \\
\hline Industrial & 1 & 27.8 & 8.26 & 0.005 \\
Mangrove & 1 & 30.03 & 5.79 & 0.005 \\
Forest & 1 & 34.31 & 5.27 & 0.005 \\
Urbanized & 1 & 38.42 & 5.92 & 0.005 \\
A. officinalis & 1 & 40.25 & 3.59 & 0.005 \\
Agriculture & 1 & 41.45 & 2.93 & 0.01 \\
Salinity & 1 & 41.85 & 2.15 & 0.04 \\
\hline
\end{tabular}

A. marina was found to hold the highest species importance (IV) in Penang, Malaysia (Table 1). The high IV of A. marina indicates the important contribution that A. marina made to the mangrove forest structure of Penang, Malaysia, in terms of tree density, stand basal area (SBA), and tree frequency. The finding of one tree species that dominates IV is not uncommon within the IWP with example of Rhizophora apiculata dominating IV in Klang Island, Malaysia (Norhayati et al. 2009), and in Sibuti, Sarawak, Malaysia (Shah et al. 2016), and Sonneratia alba dominating IV in East Lombok Regency, West Nusa Tenggara Aminuddin and Sunarto (2019). While in the mangrove forests of Teluk Gong, Malaysia (Rozainah et al. 2018); Pulau Ketam, Malaysia (Rozainah et al. 2018); and Kerala, India, IV (George et al. 2019) is more evenly distributed among two or more tree species. These studies note abiotic, biotic, human disturbance, and nature conservation as key influences that shape the mangroves forest's structure and IV (Norhayati et al. 2009; Shah et al. 2016; Rozainah et al. 2018; George et al. 2019; Aminuddin and Sunarto 2019).

Salinity is known to be a limiting factor for mangrove trees (Krauss and Ball 2013; Marisa and Sarno 2015). Salinity could limit mangrove diversity and the ability of other mangrove species to contribute to IV in Penang. Ideal salinity for
Table 4 All abiotic factors taken into consideration including waste by percentage at vegetation plot, dissolved oxygen (DO) $\mathrm{mg} / \mathrm{l}$, temperature in degrees Celsius $\left({ }^{\circ} \mathrm{C}\right.$ ), $\mathrm{pH}$, salinity (PSU), and sediment texture (score from 1-4) with standard deviation. Mann-Whitney $U$ test was used to show significant differences between urban and rural sites with significant levels marked as follows: $*<0.05, * *<0.01, * * *<0.001$

\begin{tabular}{|c|c|c|c|c|c|c|c|c|c|}
\hline & All sites & Urban & Rural & PP & TAT & $\mathrm{BP}$ & FTZ & JEL & SS \\
\hline Waste (\%) & $19.93 \pm 29.18$ & $38.29 \pm 32.04 * * *$ & $2.57 \pm 8.55^{* * *}$ & 0 & $2.08 \pm 3.34$ & $2.00 \pm 4.22$ & $32.50 \pm 21.37$ & $73.64 \pm 21.11$ & $11.67 \pm 15.86$ \\
\hline DO (mg/l) & $6.43 \pm 3.11$ & $6.22 \pm 3.88^{*}$ & $6.64 \pm 2.20 *$ & $5.94 \pm 1.49$ & $9.02 \pm 1.62$ & $4.97 \pm 1.12$ & $6.08 \pm 1.18$ & $4.40 \pm 0.86$ & $8.02 \pm 6.12$ \\
\hline Temp $\left({ }^{\circ} \mathrm{C}\right)$ & $21.86 \pm 1.70$ & $21.50 \pm 2.15$ & $22.21 \pm 1.04$ & $21.79 \pm 1.50$ & $22.1 \pm 0.44$ & $22.48 \pm 0.54$ & $23.48 \pm 0.34$ & $22.36 \pm 0.55$ & $18.73 \pm 0.77$ \\
\hline $\mathrm{pH}$ & $6.51 \pm 3.76$ & $6.54 \pm 4.92$ & $6.48 \pm 2.23$ & $5.6 \pm 1.23$ & $9.02 \pm 1.62$ & $4.82 \pm 1.13$ & $9.12 \pm 7.29$ & $4.40 \pm 0.86$ & $6.04 \pm 3.77$ \\
\hline $\begin{array}{l}\text { Salinity } \\
\text { (PSU) }\end{array}$ & $14.40 \pm 7.60$ & $10.3 \pm 5.70^{* * *}$ & $18.40 \pm 7.20 * * *$ & $15.6 \pm 8.5$ & $22.8 \pm 6.5$ & $16.2 \pm 5.0$ & $13.30 \pm 5.00$ & $7.10 \pm 4.50$ & $9.80 \pm 5.80$ \\
\hline $\begin{array}{l}\text { Substrate } \\
\text { texture }\end{array}$ & $2.16 \pm 1.04$ & $2.61 \pm 1.27$ & $1.92 \pm 0.63$ & $1.66 \pm 0.49$ & $2.08 \pm 0.28$ & $2.00 \pm 0.95$ & $3.33 \pm 1.61$ & $2.66 \pm 0.78$ & $1.83 \pm 1.03$ \\
\hline
\end{tabular}




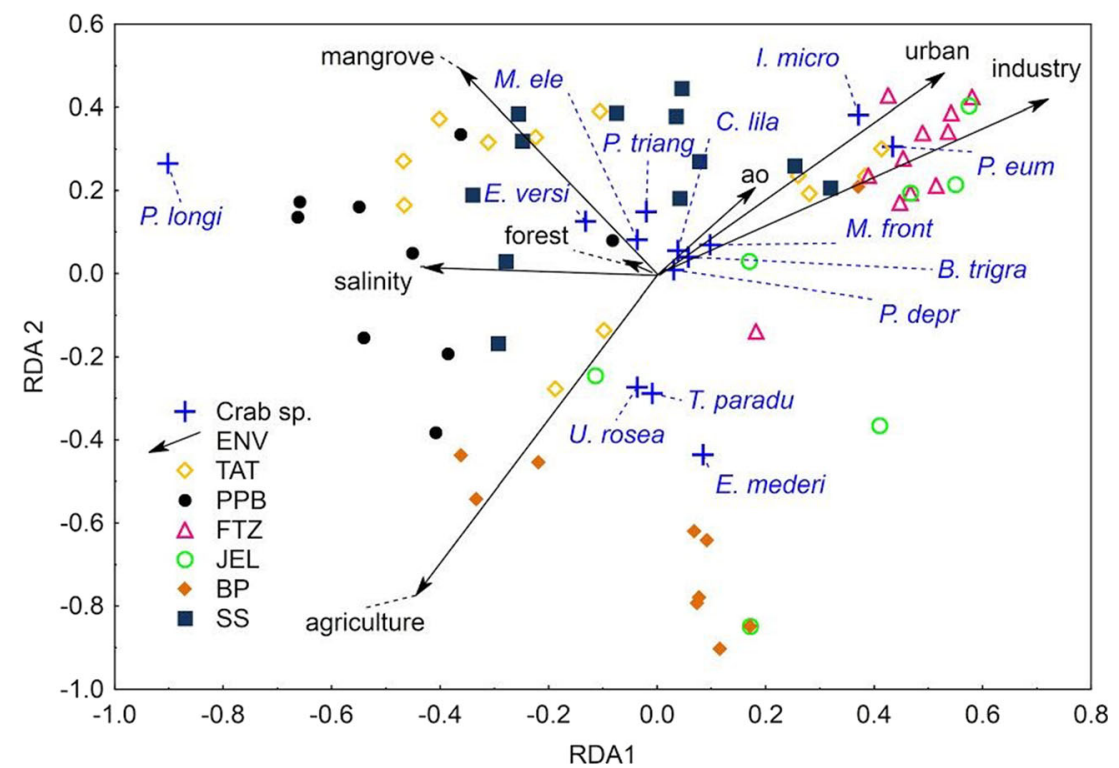

Fig. 3 Results of redundancy analysis (RDA). Adjusted $\mathrm{R}^{2}=0.32$. RDA illustrates the impact of environmental and land use data on crab community pattern after forward selection of variables. Crab community data as sampled in different study sites (see legend) have been regressed on abiotic or land use data represented by arrows (ENV), sites are distinguished by shape, and taxa scores are shown by blue crosses and abbreviated name in italics. Abbreviations for species scores are as follows: B. trigr, Baruna trigranulum; C. lila, Coenobita lila; E. med, Episesarma mederi; E. vers, Episesarma versicolor; U. ros, Tubuca rosea; M. ele, Metaplax elegans; M. front, Metopograpsus frontalis; I. micro, I. microcheirum; P. eum, Parasesarma eumolpe; P. longi, Parasesarma longicristatum; P. dep, Paracleistostoma depressum; P. train, Austruca triangularis; U. parad, Tubuca paradussumieri. Environmental data are abbreviated as follows: ao, sites covered with mangrove tree Avicennia officinalis; salinity, salt content. Agriculture, mangrove, urban, and industry mark different land use patterns. Abbreviation for study sites are as follows: BP, Balik Pulau; PPB, Permatang Pasir; TAT, Teluk Ayer Tawar; FTZ, Free Trade Zone; JEL, Jelutong; and SS, Sungai Sembilang

A. marina is 15 PSU (Krauss and Ball 2013), and considering the entire study area, the average salinity was $14.5 \pm 7.7$ PSU. In urban sites, a lower salinity of $10.4 \pm 5.7$ PSU was observed allowing less salinity resistance genera Sonneratia and Bruguiera to establish (Marisa and Sarno 2015). All three urban sites were located near mouths of streams which may have reduced salinity of the water. Rural sites had significantly higher salinity, $18.4 \pm 7.3$ PSU that may have prevented establishment of salinity-intolerant species. Other than salinity, only waste covering the forest floor and dissolved oxygen varied significantly between urban and rural sites.

In this study of Penang, 13 crab species were recorded, a lower number of species compared to several studies completed in the IWP. Three additional crab species Varuna yui (paddler crab), Myomenippe hardwickii (thunder crab), and Scylla $\mathrm{sp}$. were observed during fieldwork but were not present within collection quadrats. Crab assemblages vary with the total number of crab species throughout the IWP. In the Segara Anakan lagoon, Indonesia, $47 \mathrm{crab}$ species were recorded (Geist et al. 2012); in Port Swettenham, Malaysia, $34 \mathrm{crab}$ species were recorded (Sasekumar 1974); and in Sarawak, Malaysia, 28 crab species were recorded (Ashton et al. 2003). However, at Matang, Malaysia (Sasekumar and Chong 1998), and at Marudu Bay, Sabah, Malaysia (Zakaria and Rajpar 2015), only seven crab species were reported indicating that the result of this study was not atypically low for the IWP region. Similar studies on benthic invertebrates and brachyuran crab species might have found different number of species due to difference in collection methodologies and research aims.

Comparing crab communities in terms of species density and biomass from Penang to other mangroves in the IWP found similar trends (Jones 1984). Superfamilies Grapsoidea and Ocypodoidea had similar densities, while Grapsoidea had higher biomass values when compared to Ocypodoidea (Jones 1984; Geist et al. 2012). These results are similar to findings from Tan and Ng (1994) that crabs belonging to the family Sesarmidae are the dominant group in dense mangrove forests. After a thorough review of the literature, no additional crab species were recorded in the mangrove forests of Penang (Crane 1975; Tan and Ng 1994). Although all species were expected in Malaysia from previous baseline inventories, several species were not observed during field survey (Crane 1975; Tan and Ng 1994). Field surveys were conducted during low tide during the sunlight hours (8:00-18:00), which could have affected species composition. Only crabs within collection quadrats were recorded and added to analysis. Movement and disturbance in the mangrove forest by researchers might have perturbed crabs causing sensitive crabs to hide (Kent and McGuinness 2006). While other treeclimbing crabs from the family Grapsidae and Sesarmidae might have been out of range for capture (Kent and 
McGuinness 2006). In addition, Episesarma spp. could have escaped into the depth of their burrows, and smaller crabs (Paracleistostoma spp. and Ilyogynnis spp.) could have been underestimated due to their miniscule size (Kent and McGuinness 2006).

In similar studies of mangrove crabs, often diversity indices are not used in uniform, are not included in analyses, or include non-brachyuran invertebrates and vertebrates (Sasekumar 1974; Sasekumar and Chong 1998; Norhayati et al. 2009; Zakaria and Rajpar 2015). Lack of consistency among studies in reporting crab diversity indices creates difficulties for study comparisons. In studies that focused on brachyuran diversity within the mangrove forest, similar Shannon's indices were noted (Macintosh et al. 2002; Ashton et al. 2003; Geist et al. 2012). Yet, studies that focused on brachyuran communities had different research objectives which impacted the reported Shannon index. Ashton et al. (2003) created a baseline of biodiversity and found an overall high Shannon index (2.60) in the near pristine mangroves of Sarawak, Malaysia. Macintosh et al. (2002) investigated the associations of mangrove rehabilitation onto crab communities and found a low Shannon index in a misused tin mine (0.46) and a high Shannon index (2.12) in mature mixed mangrove forest. Geist al. (2012) investigated the humaninfluenced mangrove forests of Segara Anakan lagoon, Indonesia. In the central mangrove forests of Segara Anakan lagoon, a lower Shannon index (2.0) was reported compared to the eastern portion of the mangrove forests (2.7) (Geist et al. 2012). Geist et al. (2012) found a low Shannon index in a shrimp pond during the dry season $(0.7)$ and a high Shannon index (2.1 and 1.7) in a mangrove forest near an oil refinery in the dry and rainy season. This study of crab communities of Penang reported relatively high Shannon index (2.08) in urban mangrove forests and a lower Shannon index (1.72) in rural mangrove forests.

In the multivariate analysis (RDA), all abiotic, land use data, and tree abundance data were considered. The findings suggest that land use, salinity, and A. officinalis abundance data were the significant contributors in describing crab occurrence in Penang, Malaysia. Of the six abiotic factors recorded in this study, the RDA model selected only salinity. Salinity was expected as an explanatory factor for crab occurrence, since salinity has been detailed in numerous studies as a limiting factor for flora and fauna in intertidal zones (Sandilyan et al. 2010; Josefson 2016; Obolewski et al. 2018). Salinity is considered a limiting factor to crab species specifically Parasesarma longicristatum and Metaplax elegans that have been documented as poor osmoregulators (Macintosh 1984; Geist et al. 2012). Differences in salinities at the site level may contribute to the higher abundances of certain crab species ( Macintosh 1984; Geist et al. 2012). Of the 14 mangrove tree species present in the study, the RDA model only selected abundance of $A$. officinalis to describe crab occurrence in Penang. Potentially, low leaf litter diversity in the Avicennia dominated mangrove forest of Penang, Malaysia, and food preferences assist in the explanation of crab occurrence (Macintosh et al. 2002; Ya et al. 2008). The most obvious direct impact of urbanization on biodiversity is land use change of native ecosystems (Müller et al. 2013). The remaining five biplots of the RDA are the land use types: mangrove forest, urban areas, industrial area, non-mangrove forest, and agricultural. This result reflects work from other researchers that found land use change from urbanization and human development to be an important influencer to coastal biodiversity (Güneralp and Seto 2013).

The impacts of urbanization onto biodiversity are not selfevident. A review from McKinnely in 2008 investigated 105 empirical studies that focused on the impacts of urbanization onto species richness. The review concluded that urbanization can both increase and decreases species richness based on the intensity of urbanization. The majority of studies (65\%) found an increase of plant species richness in moderately urbanized settings (McKinney 2008), similar to this study's findings of increased mangrove tree diversity (Table 3 ) and undergrowth species in urban forests (Table 1). Similar findings for invertebrates were highlighted in the review but the increase of invertebrate species richness was less intense (30\%) (McKinney 2008). In this study, no effect from urbanization was observed to crab species richness or number of crabs (Table 3). Yet this study of Penang, Malaysia, found that certain crab species densities or biomasses are significantly higher in either urban or rural mangrove forests (Table 2). McKinnely (2008) indicated that plant species richness and invertebrate species richness were reduced in extremely urban cores. Increased species richness in moderately urbanized areas were attributed to invasion of nonnative species, intermediate disturbance, and the scale of study size (McKinney 2008).

In conclusion, this study in Penang, Malaysia, produced insights to the impacts of urbanization onto mangrove forests and crab assemblages and their interconnectedness. This study emphasizes that crab assemblages are not only correlated to mangrove vegetation and the abiotic environment but additionally to land use as revealed by RDA. Considering the mangrove forest structure based on IV, both urban and rural sites were found to be quite similar. Yet, a higher number of tree species (14) were found in urban compared to rural sites (7). Considering the crab assemblages in this study, species richness (d) was not directly impacted by urbanization although higher crab diversity $\left(\mathrm{H}^{\prime}\right)$ and crab evenness $(\mathrm{J})$ was observed at urban sites. This study demonstrated that smaller fragmented urban mangroves at the east coast of Penang have a relatively high tree and crab diversity and are worth protecting, in addition to the larger mangrove forests on the west coast. The preservation of small yet interconnected mangrove sites could be critical to the recruitment of their flora and 
fauna and should be considered in decision-making processes. Long-term monitoring of study sites is recommended to reveal long-term trends associated with urbanization onto mangrove forests and their crab assemblages. Resource managers can draw on these findings to better manage the remaining patches of mangroves in Penang, Malaysia.

Supplementary Information The online version contains supplementary material available at https://doi.org/10.1007/s10113-021-01800-3.

Acknowledgements We thank Centre for Marine and Coastal Studies (CEMACS) and Universiti Sains Malaysia (USM) for providing transportation, equipment, and laboratory space for this study. We are grateful for Yee Jean Chai, Marcus Loh, Jian Rong, and Amni Nabilah Mat Adam who gave their assistance in fieldwork. We are also thankful for Leibniz Center for Tropical Marine Research for the 5000 euro grant for the BAKAU project.

Funding Open access funding provided by Uppsala University.

Open Access This article is licensed under a Creative Commons Attribution 4.0 International License, which permits use, sharing, adaptation, distribution and reproduction in any medium or format, as long as you give appropriate credit to the original author(s) and the source, provide a link to the Creative Commons licence, and indicate if changes were made. The images or other third party material in this article are included in the article's Creative Commons licence, unless indicated otherwise in a credit line to the material. If material is not included in the article's Creative Commons licence and your intended use is not permitted by statutory regulation or exceeds the permitted use, you will need to obtain permission directly from the copyright holder. To view a copy of this licence, visit http://creativecommons.org/licenses/by/4.0/.

\section{References}

Alongi DM (2002) Present state and future of the world's mangrove forests. Environ Conserv 29(3):331-349. https://doi.org/10.1017/ S0376892902000231

Aminuddin M, Sunarto PD (2019) Mangrove forest community structure in Ekas Buana Village, East Lombok Regency, West Nusa Tenggara. AIP Conf Proc 2120(1):040019. https://doi.org/10.1063/ 1.5115657

Ashton EC (2002) Mangrove sesarmid crab feeding experiments in Peninsular Malaysia. J Exp Mar Biol Ecol 273(1):97-119. https:// doi.org/10.1016/S0022-0981(02)00140-5

Ashton EC, Macintosh DJ, Hogarth PJ (2003) A baseline study of the diversity and community ecology of crab and molluscan macrofauna in the Sematan mangrove forest, Sarawak, Malaysia. J Trop Ecol 19(2):127-142. https://doi.org/10.1017/S0266467403003158

Branoff BL (2017) Quantifying the influence of urban land use on mangrove biology and ecology: a meta-analysis. Glob Ecol Biogeogr 26(11):1339-1356. https://doi.org/10.1111/geb.12638

Chee SY, Othman AG, Sim YK, Mat Adam AN, Firth LB (2017) Land reclamation and artificial islands: walking the tightrope between development and conservation. Glob Ecol Conserv 12:80-95. https://doi.org/10.1016/j.gecco.2017.08.005
Crane J (1975) Fiddler crabs of the world: Ocypodidae: Genus Uca. Princeton University Press, Princeton

Davie PJF (1992) Revision of Sarmatium DANA (Crustacea: Brachyura: Sesarminae) with descriptions of three new species. Mem Queensl Mus 32:79-97

Davie PJF (1994) Variations in diversity of mangrove crabs in tropical Australia. Mem Queensl Mus 36(1):55-58

Davie P (2003) A new species of Perisesarma (Crustacea: Brachyura: Sesarmidae) from the Bay of Bengal. Raffles Bull Zool 51(2):387391

Davie PJF, Pabriks L (2010) A new species of Parasesarma (Crustacea: Brachyura: Sesarmidae) from the mangroves of Western Australia. Zootaxa 2564(1):62-68. https://doi.org/10.11646/zootaxa.2564.1.4

Department of Statistics Malaysia (2015) Jumlah penduduk dan kepadatan penduduk mengikut daerah pentadbiran bagi negeri Pulau Pinang, 2014-2015

Ellison AM (2008) Managing mangroves with benthic biodiversity in mind: moving beyond roving banditry. J Sea Res 59(1):2-15. https://doi.org/10.1016/j.seares.2007.05.003

English S, Wilkinson C, Baker V (1994) Survey manual for tropical marine resources. Australian Institute of Marine Science, Townsville

FAO (2007) Forestry paper. The world's mangroves 1980-2005. Food and Agriculture Organization, Rome 21-28

Friess DA, Phelps J, Leong RC, Lee WK, AKS W, Sivasothi N, Oh RRY W (2012) Mandai mangrove, Singapore: lessons for the conservation of Southeast Asia's mangroves. Raffles Bull Zool 25:55-65

Geist SJ, Nordhaus I, Hinrichs S (2012) Occurrence of species-rich crab fauna in a human-impacted mangrove forest questions the application of community analysis as an environmental assessment tool. Estuar Coast Shelf Sci 96:69-80. https://doi.org/10.1016/j.ecss. 2011.10.002

George G, Krishnan P, Mini KG, Salim SS, Ragavan P, Tenjing SY, Muruganandam R, Dubey SK, Gopalakrishnan A, Purvaja R, Ramesh R (2019) Structure and regeneration status of mangrove patches along the estuarine and coastal stretches of Kerala, India. J For Res 30(2):507-518. https://doi.org/10.1007/s11676-018-06002

Giesen W, Wulffraat S, Zieren M, Scholten L (2007) Mangrove guidebook for Southeast Asia. FAO Regional Office for Asia and the Pacific, Bangkok

Giri C, Ochieng E, Tieszen LL, Zhu Z, Singh A et al (2011) Status and distribution of mangrove forests of the world using earth observation satellite data. Glob Ecol Biogeogr 20(1):154-159. https://doi.org/ 10.1111/j.1466-8238.2010.00584.x

Goessens A, Satyanarayana B, der Stocken TV, Zuniga MQ, MohdLokman $H$ et al (2014) Is Matang Mangrove Forest in Malaysia sustainably rejuvenating after more than a century of conservation and harvesting management? PLoS One 9(8):e105069. https://doi. org/10.1371/journal.pone.0105069

Güneralp B, Seto KC (2013) Futures of global urban expansion: uncertainties and implications for biodiversity conservation. Environ Res Lett 8(1):014025. https://doi.org/10.1088/17489326/8/1/014025

Hinrichs S, Nordhaus I, Geist SJ (2009) Status, diversity and distribution patterns of mangrove vegetation in the Segara Anakan lagoon, Java, Indonesia. Reg Environ Chang 9(4):275. https://doi.org/10.1007/ s10113-008-0074-4

Hookham B, Shau-Hwai AT, Dayrat B, Hintz W (2014) A baseline measure of tree and gastropod biodiversity in replanted and natural mangrove stands in Malaysia: Langkawi Island and Sungai Merbok. Trop Life Sci Res 25(1):1-12

Jones DA (1984) Crabs of the mangal ecosystem. In: Por FD, Dor I (eds) Hydrobiology of the mangal. Dr. W. Junk, The Hague 89-109 
Josefson AB (2016) Species sorting of benthic invertebrates in a salinity gradient - importance of dispersal limitation. PLoS One 11(12): e0168908. https://doi.org/10.1371/journal.pone.0168908

Jusoff K, Taha D (2008) Managing sustainable mangrove forests in Peninsular Malaysia. J Sustain Dev 1(1):88-96. https://doi.org/10. 5539/jsd.v1n1p88

Kent CPS, McGuinness KA (2006) A comparison of methods for estimating relative abundance of grapsid crabs. Wetl Ecol Manag 14(1): 1-9. https://doi.org/10.1007/s11273-004-5075-6

Kitamura S, Anwar C, Chaniago A, Baba S (1997) Handbook of mangroves in Indonesia-Bali and Lombok. International Society for Mangrove Ecosystems, Okinawa

Krauss KW, Ball MC (2013) On the halophytic nature of mangroves. Trees 27(1):7-11. https://doi.org/10.1007/s00468-012-0767-7

Kristensen E (2008) Mangrove crabs as ecosystem engineers; with emphasis on sediment processes. J Sea Res 59(1):30-43. https://doi. org/10.1016/j.seares.2007.05.004

Kristensen E, Alongi DM (2006) Control by fiddler crabs (Uca vocans) and plant roots (Avicennia marina) on carbon, iron, and sulfur biogeochemistry in mangrove sediment. Limnol Oceanogr 51(4):15571571. https://doi.org/10.4319/lo.2006.51.4.1557

Lee SY (1998) Ecological role of grapsid crabs in mangrove ecosystems: a review. Mar Freshw Res 49(4):335-343. https://doi.org/10.1071/ mf97179

Lee SY (2008) Mangrove macrobenthos: assemblages, services, and linkages. J Sea Res 59(1):16-29. https://doi.org/10.1016/j.seares.2007. 05.002

Macintosh DJ (1984) Ecology and productivity of Malaysian mangrove crab populations (Decapoda: Brachyura). In: Soepadmo E, Rao AN, Macintosh DJ (eds) Proceedings of the Asian symposium on mangrove environment, research and management, Kuala Lumpur 354 377

Macintosh DJ, Ashton EC, Havanon S (2002) Mangrove rehabilitation and intertidal biodiversity: a study in the Ranong mangrove ecosystem, Thailand. Estuar Coast Shelf Sci 55(3):331-345. https://doi. org/10.1006/ecss.2001.0896

Malaysian Meteorological Department (2017) Available at: http://www. met.gov.my. Accessed 15 October

Margalef R (1958) Information theory in ecology. Gen Syst 3:36-71

Marisa H, Sarno (2015) Three species zonation of Sonneratia; based on salinity, in River Calik, South Sumatera. In: International conference on plant, marine and environmental sciences (PMES-2015) Kuala Lumpur, Malaysia, 1-2 Jan 2015

McKinney ML (2008) Effects of urbanization on species richness: a review of plants and animals. Urban Ecosyst 11(2):161-176. https://doi.org/10.1007/s11252-007-0045-4

Mohammed KS, Elhadary Y, Samat N, Omar NQ (2015) GIS and remote sensing techniques for measuring agriculture land loss in Balik Pulau region of Penang state, Malaysia. Asian J Agric Rural Dev 5(2):30-41

Müller N, Ignatieva M, Nilon CH, Werner P, Zipperer WC (2013) Patterns and trends in urban biodiversity and landscape design. In: Elmqvist T, Fragkias M, Goodness J, Güneralp B, Marcotullio PJ, McDonald RI, Parnell S, Schewenius M, Sendstad M, Seto KC, Wilkinson $\mathrm{C}$ (eds) Urbanization, biodiversity and ecosystem services: challenges and opportunities: a global assessment. Springer Netherlands, Dordrecht 123-174. https://doi.org/10.1007/978-94007-7088-1 10

Nagelkerken I, Blaber SJM, Bouillon S, Green P, Haywood M et al (2008) The habitat function of mangroves for terrestrial and marine fauna: a review. Aquat Bot 89(2):155-185. https://doi.org/10.1016/ j.aquabot.2007.12.007

Ng PKL, Guinot D, Davie PJF (2008) Systema brachyurorum: part I. An annotated list of extant brachyuran crabs of the world. Raffles Bull Zool 17:1-286
Nordhaus I, Hadipudjana FA, Janssen R, Pamungkas J (2009) Spatiotemporal variation of macrobenthic communities in the mangrovefringed Segara Anakan lagoon, Indonesia, affected by anthropogenic activities. Reg Environ Chang 9(4):291-313. https://doi.org/10. 1007/s10113-009-0097-5

Norhayati A, Shukor MN, Juliana S, Wan Juliana WA (2009) Mangrove flora and fauna of Klang islands mangrove forest reserves, Selangor, Malaysia. Malaysian J Sci 28:275-288. https://doi.org/10.22452/ mjs.vol28no3.6

Obolewski K, Glińska-Lewczuk K, Szymańska M, Mrozińska N, Bakowska $\mathrm{M}$ et al (2018) Patterns of salinity regime in coastal lakes based on structure of benthic invertebrates. PLOS ONE 13(11): e0207825. https://doi.org/10.1371/journal.pone.0207825

Pielou EC (1966) The measurement of diversity in different types of biological collections. J Theor Biol 13:131-144. https://doi.org/10. 1016/0022-5193(66)90013-0

Primavera JH, Sadaba RB, Lebata MJH, Altamirano JP (2004) Handbook of mangroves in the Philippines-Panay. SEAFDEC Aquaculture Department, Iloilo

Pülmanns N, Diele K, Mehlig U, Nordhaus I (2014) Burrows of the semiterrestrial crab Ucides cordatus enhance $\mathrm{CO} 2$ release in a North Brazilian mangrove forest. PLoS One 9(10):e109532. https://doi. org/10.1371/journal.pone.0109532

Ribero L, Lim PE, Ramli R, Polgar G (2019) Diversity and habitat segregation of mangrove grapsoid crabs along the west coast of the Malay Peninsula. Mar Freshw Res 71(8):984-995. https://doi.org/ 10.1071/MF19147

Ribero L, Lim PE, Ramli R, Polgar G (2020) Assemblage structure, distribution and habitat type of the grapsoid crabs (Brachyura: Grapsoidea) of the coastal forested swamps of northern Borneo. Reg Stud Mar Sci 37:101323. https://doi.org/10.1016/j.rsma.2020. 101323

Ricklefs RE, Latham RE (1993) Global patterns of diversity in mangrove floras. In: Ricklefs RE, Schluter D (eds) Species diversity in ecological communities. Historical and geographical perspectives. University of Chicago Press, Chicago 215 233

Ricklefs RE, Schwarzbach AE, Renner SS (2006) Rate of lineage origin explains the diversity anomaly in the world's mangrove vegetation. Am Nat 168(6):805-810. https://doi.org/10.1086/508711

Robertson AI (1986) Leaf-burying crabs: Their influence on energy flow and export from mixed mangrove forests (Rhizophora spp.) in northeastern Australia. J Exp Mar Biol Ecol 102(2):237-248. https://doi. org/10.1016/0022-0981(86)90179-6

Rozainah MZ, Sofawi AB, Joharee NA, Pauzi AZ (2018) Stand structure and biomass estimation in the Klang Islands Mangrove Forest, Peninsular Malaysia. Environ Earth Sci 77(13):486. https://doi.org/ 10.1007/s12665-018-7636-7

Saenger P, Ragavan P, Sheue C-R, López-Portillo J, Yong JWH, et al (2019) Mangrove biogeography of the Indo-Pacific. In: Gul B, Böer B, Khan MA, Clüsener-Godt M, Hameed A (eds) Sabkha Ecosystems: Volume VI: Asia/Pacific. Springer International Publishing, Cham 379-400. https://doi.org/10.1007/978-3-03004417-6 23

Sandilyan S, Thiyagesan K, Nagarajan R, Vencatesan J (2010) Salinity rise in Indian mangroves - a looming danger for coastal biodiversity. Curr Sci 98:754-756

Sasekumar A (1974) Distribution of macrofauna on a Malayan mangrove shore. J Anim Ecol 43(1):51-69. https://doi.org/10.2307/3157

Sasekumar A, Chong VC (1998) Faunal diversity in Malaysian mangroves. Glob Ecol Biogeogr Lett 7(1):57-60. https://doi.org/10. 2307/2997697

Serène R, Soh CL (1967) Note on the five largest species of Sesarma crabs in Malaysia and Singapore. Malay Nat J 20:27-30 
Serene R, Soh CL (1970) New Indo-Pacific genera allied to Sesarma SAY 1817 (Brachyura, Decapoda, Crustacea). Treubia 27:387417

Shah K, AHM K, Rosli Z, Hakeem KR, Hoque MM (2016) Composition and diversity of plants in Sibuti mangrove forest, Sarawak, Malaysia. For Sci Technol 12(2):70-76. https://doi.org/10.1080/ 21580103.2015.1057619

Shannon CE (1948) A mathematical theory of communication. Bell Syst Tech J 27(3):379-423. https://doi.org/10.1002/j.1538-7305.1948. tb01338.x

Simpson EH (1949) Measurement of diversity. Nature 163(4148):688688. https://doi.org/10.1038/163688a0

Spalding M, Kainuma M, Collins L (2010) World atlas of mangroves. Earthscan, London

Tan CGS, Ng PKL (1994) An annotated checklist of mangrove brachyuran crabs from Malaysia and Singapore. Hydrobiologia 285(1):75-84. https://doi.org/10.1007/BF00005655

Vermeiren P, Abrantes K, Sheaves M (2015) Generalist and specialist feeding crabs maintain discrete trophic niches within and among estuarine locations. Estuar Coasts 38(6):2070-2082. https://doi. org/10.1007/s12237-015-9959-x

Wright JP, Jones CG (2006) The concept of organisms as ecosystem engineers ten years on: progress, limitations, and challenges. BioScience 56(3):203-209. https://doi.org/10.1641/00063568(2006)056[0203:TCOOAE]2.0.CO;2

Ya BP, Yeo DCJ, Todd PA (2008) Feeding ecology of Two species of Perisesarma (Crustacea: Decapoda: Brachyura: Sesarmidae) in Mandai Mangroves, Singapore. J Crustac Biol 28(3):480-484. https://doi.org/10.1651/07-2835R.1

Zakaria M, Rajpar MN (2015) Assessing the fauna diversity of Marudu Bay Mangrove Forest, Sabah, Malaysia, for future conservation. Diversity 7(2):137-148. https://doi.org/10.3390/d7020137

Publisher's note Springer Nature remains neutral with regard to jurisdictional claims in published maps and institutional affiliations. 